\title{
OVEREXPRESSION OF $G \alpha$ GENE INCREASES GROWTH AND HYPOSALINE TOLERANCE IN Kappaphycus alvarezii TRANSGENIC PLANTLETS
}

\author{
ERINA SULISTIANI ${ }^{*}$, SUHARSONO², ENCE DARMO JAYA SUPENA² AND MIFTAHUDIN2 \\ 'SEAMEO BIOTROP, Jalan Raya Tajur Km 6, Bogor 16134, Indonesia \\ ${ }^{2}$ Department of Biology, Faculty of Mathematics and Natural Sciences, \\ Institut Pertanian Bogor, Bogor 16680, Indonesia.
}

Received 4 April 2018/Accepted 27 June 2020

\begin{abstract}
$G$ proteins are membrane proteins that play roles in signal transduction in living organisms. They consist of $\alpha, \beta$ and $\gamma$ subunits. The $G$ protein $\alpha$ subunit $(G a)$ plays a role in plant resistance toward biotic and abiotic environmental stresses. Transgenic plantlets of Kappaphycus alvarezii carrying the $G a$ gene (derived from soybean) have been successfully obtained through Agrobacterium tumefaciens-mediated transformation. The present study aimed to: 1. compare the growth of non-transgenic and transgenic plantlets of $K$. alvarezii in vitro using Provasoli enriched seawater (PES) medium with normal salinity and hyposalinity and 2. analyze the expression level of the $\mathrm{Ga}$ gene in transgenic plantlets using quantitative Polymerase Chain Reaction (qPCR). The results showed that all transgenic plantlets (six clones) had significantly higher daily growth rate (DGR, \%/d) than that of nontransgenic under the condition of normal salinity $(30 \mathrm{ppt})$ and hyposalinity (15 and $20 \mathrm{ppt})$ for 5 weeks of observation. At $15 \mathrm{ppt}$, transgenic plantlets were more tolerant than non-transgenic ones, as most thalli of transgenic plantlets remained brown in color, whereas most thalli of non-transgenic plantlets were bleached. The results of the qPCR analysis showed that the expression of the Ga gene in transgenic plantlets increased by 6.43 8.03 times compared with that of non-transgenic plantlets. The result of Pearson correlation analysis showed that relative expression of $\mathrm{Ga}$ gene had a strong correlation, both with DGRs in normal salinity and hyposalinity of transgenic plantlets (correlation coefficient $>0.7$ ). The correlation was linearly positive, where increased expression of the Ga gene was strongly associated with an increase in DGRs.
\end{abstract}

Keywords: Ga gene overexpression, hyposaline tolerance, Kappaphycus alvarezii, transgenic plantlet

\section{INTRODUCTION}

Kappaphycus alvarezii Doty is a commercially important species of red algae (Rhodophyta) that is known in the trade as 'Cottonii seaweed'. This species is the main source of kappa $(x)$ carrageenan, which is widely used in the pharmaceutical, food and cosmetics industries. $K$ alvarezii is widely cultivated in coastal waters of Indonesia and Philippines. However, in the cultivation of $K$. alvarezii in coastal waters, major problems may occur such as salinity change and other frequent pronounced fluctuations in environmental factors in coastal waters. K. alvarezii grows at a salinity of $28-34$ ppt (part

Corresponding author, email: esulistiani@biotrop.org per thousand) (Parenrengi et al. 2011). However, in rainy season with heavy rainfall, the salinity of seawater can decrease up to below $28 \mathrm{ppt}$. The decrease of salinity subjects the seaweed to hyposaline stress. The stress can cause the occurrence ice-ice disease in seaweed, which symptoms include slow growth, bleaching and decay of some or all of the thalli (Parenrengi et al. 2011). To overcome the impacts of ice-ice disease in seaweed, a genetic transformation needs to be done to obtain $K$. alvarezii that is tolerant to hyposaline stress.

The heterotrimeric $G$ proteins are membrane proteins consisted of the $\alpha, \beta$ and $\gamma$ subunits $(G \alpha, G \beta$ and $G \gamma$ ) (Urano et al. 2013). They play a role in signal transduction in a living organism as mediators that send extracellular signals from 
receptor molecules in the cell membrane to effector molecules. In plants, $G \alpha$ proteins play a role on cell growth, cell proliferation, defense against disease, stomatal movement, channel regulation, sugar sensing and some hormonal responses (Urano et al. 2013). Moreover, according to Chakraborty et al. (2015), G $\alpha$ proteins play a role in plant resistance to biotic and abiotic environmental stresses.

Seaweeds respond to changes in salinity by adjusting the balance of osmotic potential between internal and external cells via pumping of inorganic ions such as $\mathrm{K}^{+}, \mathrm{Na}^{+}$and $\mathrm{Cl}^{-}$into or out of the cells (Karsten 2012). The influx of external $\mathrm{Ca}^{2+}$ into the cytoplasm facilitates the maintenance of $\mathrm{K}^{+}$and $\mathrm{Na}^{+}$homeostasis during salinity stress because $\mathrm{Ca}^{2+}$ plays a role in activating the $\mathrm{Na}^{+} / \mathrm{H}^{+}$Salt-Overly-Sensitive1 (SOS1) antiporter and the cation $/ \mathrm{H}^{+}$NHX antiporter (Hasegawa 2013). In hyposaline condition, $\mathrm{Ca}^{2+}$ also plays a role in reducing the permeability of the plasma membrane to other ions, thereby reducing ion loss that occurs during water influx (Hurd et al. 2014). In addition, $\mathrm{Ca}^{2+}$ plays a role in the regulation of aquaporin, which is a water channel protein (Gilliham et al. 2011) recently found in algal cell plasma membranes as well (Anderberg et al. 2011). $\mathrm{G} \alpha$ protein signaling plays a role in $\mathrm{Ca}^{2+}$ influx to the cytoplasm, owing to the ability of $\mathrm{G} \alpha$ protein in regulating $\mathrm{Ca}^{2+}$ channels in plasma membranes (Gelli et al. 1997; Aharon et al. 1998; Thuleau et al. 1998; Zhang et al. 2011).

Based on the above description, overexpression of the $G a$ gene in K. alvarezii is expected to increase $\mathrm{Ca}^{2+}$ influx to the cytoplasm and increase the tolerance of this seaweed to hyposaline stress $(<28 \mathrm{ppt}$ ). Transgenic plantlets of $K$. alvarezii carrying the $G a$ gene (derived from soybean) have been successfully obtained through Agrobacterium tumefaciens-mediated transformation (Sulistiani et al. 2019). The study aimed to: 1 . conduct growth performance test of non-transgenic and transgenic plantlets of $K$. alvarezii in an in vitro culture medium with normal salinity and hyposalinity and 2 . analyze the expression level of the $G a$ gene in non-transgenic and transgenic plantlets using qPCR method.

\section{MATERIALS AND METHODS}

\section{Growth Performance Test of Non- transgenic Plantlets in Hyposaline Condition}

Non-transgenic plantlets were regenerated from callus which induced from apical thallus of K. alvarezii (collected from Takalar, South Sulawesi, Indonesia). The callus was grown into plantlets by culturing the plantlets in Provasoli Enriched Seawater (PES) medium (Provasoli 1968) for 6 months (Sulistiani \& Yani 2014). The experiment was conducted to observe the growth of non-transgenic plantlets in PES medium with normal salinity and hyposalinity. The plantlets (about $3 \mathrm{~g}$ ) were grown in an aerated culture for 12 weeks with five treatments, i.e., PES with 5 different salinity levels: $15,20,25,30$, and 35 ppt $(1,000$ $\mathrm{mL} /$ bottle). Each treatment was conducted in three replicates. The cultures were continuously aerated with an air blower and placed in a culture room at temperature of $22-24{ }^{\circ} \mathrm{C}$, lighting of 1,500 lux and a $12: 12$-h light and dark cycle. The medium was replenished weekly.

The natural seawater used in this study had a salinity level of $32 \mathrm{ppt}$. The lower-than-32-ppt salinity level was prepared by adding distilled water to the natural seawater and stirring the solution using a magnetic stirrer until the desired salinity level was reached. In contrast, to obtain salinity level of more than $32 \mathrm{ppt}, \mathrm{NaCl}$ was added to the natural seawater and stirred until reaching the desired salinity level. Salinity was measured using a refractometer. The plantlets were weighed weekly, and the daily growth rates (DGRs, \%/d) were calculated using the formula of Dawes et al. (1994):

DGR $=\frac{\operatorname{Ln}(\text { final weight })-\operatorname{Ln}(\text { initial weight })}{\text { no. of days }} \times 100$

Seawater with salinity level causing significant stress and decreased DGRs in the nontransgenic plantlets was used in the growth performance tests of transgenic plantlets in a hyposaline medium to select transgenic plantlets with tolerance to hyposalinity. 


\section{Tolerance Test of Transgenic Plantlets in} Hyposaline Condition

An experiment was conducted to determine the tolerance of transgenic plantlets in PES medium with hyposaline condition, which exerted stress on the non-transgenic plantlets. Six clones of transgenic plantlets (L1, E2, E5, E6, E7 and E8) were selected from a previous study. PCR analysis was used to confirm that the transgenic plantlets carried the $G a$ gene with a constitutive promoter CaMV 35S (Sulistiani et al. 2019). Transgenic plantlets were regenerated from genetically transformed callus using the same method as that used for the nontransgenic plantlets.

The transgenic plantlets (about $0.3 \mathrm{~g}$ ) were grown in $500 \mathrm{~mL}$ of PES medium with three different salinity: $30 \mathrm{ppt}$ (normal salinity), $20 \mathrm{ppt}$ and $15 \mathrm{ppt}$ (hyposalinity). For comparison (control), non-transgenic plantlets were also grown in the same salinity treatments. The experiment was conducted for 5 weeks, with each salinity treatment being performed in three replicates. The plantlets were weighed weekly and the DGRs were calculated. One sample of each of the non-transgenic and transgenic plantlets (each about $4 \mathrm{~g}$ ) was taken for calcium content analysis. The method of analysis was based on SNI 2354.5: 2011 (BSN- National Standardization Agency of Indonesia 2011), and the calcium content was measured using an Atomic Absorption Spectrophotometer (AAS).

\section{Quantification of $G \alpha$ Gene Expression in Transgenic Plantlets using qPCR}

Total RNA was extracted from two clones of putative transgenic plantlets and one clone of non-transgenic plantlets of $K$. alvarezii (6 months old in an aerated culture) using TRIzol ${ }^{\circledR}$ reagent (Invitrogen), and cDNA was synthesised using the Iscript ${ }^{\text {TM }}$ cDNA synthesis kit (Bio-Rad). Extractions of total RNA and synthesis of cDNA were performed with three biological replicates for each clone. Quantification of $G a$ gene expression in transgenic and nontransgenic of $K$. alvarezii was performed using Quantitative Polymerase Chain Reaction (qPCR) Applied Biosystems StepOnePlus ${ }^{\mathrm{TM}}$ Real-Time PCR System. The $G a$ cDNA was amplified using the specific primer GA-F 5'- CAC GAG GTT GCT TTC TAG TTT C -3 'and GA-R 5'-
ATG AGC TTC ACG AAA ACG AC -3'. The actin gene of $K$. alvarezii was used as an internal control of gene expression with the following specific primers: K-Act-F: 5'-CCG TCC CGA TTT ACG AGG GTTA-3' and K-Act-R: 5'GCA TGA GGA GCT TCG CCA TCC-3' (Rajamuddin 2016). The $G a$ cDNA and actin cDNA were amplified in two replicates for each biological replicate.

qPCR for $G a$ cDNA and actin cDNA was performed in a $10 \mu \mathrm{L}$ reaction volume containing $200 \mathrm{ng}$ cDNA, 2.5 pmol forward primer, $2.5 \mathrm{pmol}$ reverse primer, $5 \mu \mathrm{L}$ of SYBR $^{\mathrm{TM}}$ Select Master Mix and nuclease-free water. The cDNA $G a$ gene was amplified as follows: pre-denaturation at $95{ }^{\circ} \mathrm{C}$ for $3 \mathrm{~min}$, followed by 40 cycles of denaturation at $94{ }^{\circ} \mathrm{C}$ for $10 \mathrm{~s}$, and annealing at $57{ }^{\circ} \mathrm{C}$ for $40 \mathrm{~s}$. The amplification of actin cDNA was performed using the same protocol as that followed for $G a$ cDNA, except that annealing was performed at $55^{\circ} \mathrm{C}$. Quantification of the expression level was based on the expression of $G a$ cDNA relative to that of the reference gene (actin gene of $K$. alvarezii) using the $2^{-\Delta \Delta C t}$ method. The calculation was performed by comparing the value of $\mathrm{Ct}$ (cycle threshold) from the expression of the two genes. Relative gene expression was represented by $2^{-\Delta \Delta \mathrm{Ct}}$, where $\Delta \Delta \mathrm{Ct}=\Delta \mathrm{Ct}$ transgenic $-\Delta \mathrm{Ct}$ non-transgenic and $\Delta \mathrm{Ct}=\mathrm{Ct}$ target gene $-\mathrm{Ct}$ reference gene (Livak \& Schmittgen 2001).

\section{Statistical Analysis}

Statistical analyses of DGR data were determined using analysis of variance (ANOVA) and Duncan's Multiple Range Test. The statistical analyses were performed in IBM SPSS Statistics 19.0 for Windows.

\section{RESULTS AND DISCUSSION}

\section{Effect of Salinity on Growth and Development of Non-transgenic Plantlets}

The results of statistical analysis showed that the salinity of the culture medium significantly affected the DGRs of $K$. alvarezii plantlets. The highest DGRs upon cultured for 12 weeks in PES medium were obtained at salinity of $25-30$ ppt $(1.9$ - 2.4\%/d; Fig. 1). Based on the 
literature, the seaweed $K$. alvarezii grows well in coastal waters with a salinity of $28-34 \mathrm{ppt}$ (Parenrengi et al. 2011). The results of this study showed that $K$. alvarezii plantlets cultured in PES medium with a salinity of $25 \mathrm{ppt}$ still grew optimally, showing no significant difference from the DGRs of plantlets at a salinity of $30 \mathrm{ppt}$. At a salinity of $20 \mathrm{ppt}$, the plantlets still survived, but their DGRs were lower than DGRs of plantlets at a salinity of $30 \mathrm{ppt}$. This suggests that $K$. alvarezii plantlets that were regenerated from callus through somatic embryogenesis were tolerant to hyposalinity in vitro up to $20 \mathrm{ppt}$ salinity.

In hyposaline condition, the $\mathrm{Na}^{+}$ concentration outside seaweed cells is lower than that inside the cells. Therefore, water flows enter the cells following the osmotic gradient, which in turn increases the volume of cells and their turgor. Under these conditions, the cells perform an osmotic adjustment mechanism by pumping inorganic ions such as $\mathrm{K}^{+}, \mathrm{Na}^{+}$and $\mathrm{Cl}$ in and out from the apoplast to cytoplasm until the conditions return to the normal turgor pressure and homeostasis of $\mathrm{K}^{+} / \mathrm{Na}^{+}$is achieved (Hurd et al. 2014). The decrease of DGRs upon exposure to hyposaline stress is due to the seaweed cells allocating most of their metabolic energy to the osmotic adjustment process, which in turn reduces the amount of metabolic energy used for growth (Karsten 2012). The growth decline is also due to the reduction of photosynthesis efficiency and photosynthetic fixation caused by the formation of Reactive
Oxygen Species (ROS) during hyposaline stress (Liu et al. 2012).

At $15 \mathrm{ppt}$ salinity, DGRs of $K$. alvarezii plantlet were significantly lower than those at 20 - 35 ppt salinity levels (Fig. 1). The weekly data indicated that the DGRs of plantlets cultivated in 15 ppt salinity level decreased during the first week of experiment (Fig. 2). At that time, the most of thallus plantlets changed color from reddish brown to white (bleaching), which indicated that most of the thallus cells had died. The lowest DGR occurred in the third week $(-0.1 \% / \mathrm{d})$, in which some of the bleached thalli began to soften and brittle, which reduced the plantlet weight compared to that at the beginning of the experiment. Hayashi et al. (2010) also cultured pieces of $K$. alvarezii thallus originating from coastal waters in culture media with 15 ppt salinity level, the thallus experienced bleaching and died within three days. The osmotic adjustment mechanism was unsuccessful with extreme hyposaline stress $(15 \mathrm{ppt})$, resulting in damage to the membranes, organelles and enzymes and ultimately seaweed cell death (Hurd et al 2014). In contrast, at 20 ppt salinity level, the decrease in the DGRs was not as severe as that at 15 ppt salinity level, because the thalli did not undergo bleaching. These results suggested that non-transgenic plantlets of $K$. alvarezii were not resistant or sensitive to hyposaline stress at 15 ppt salinity level.

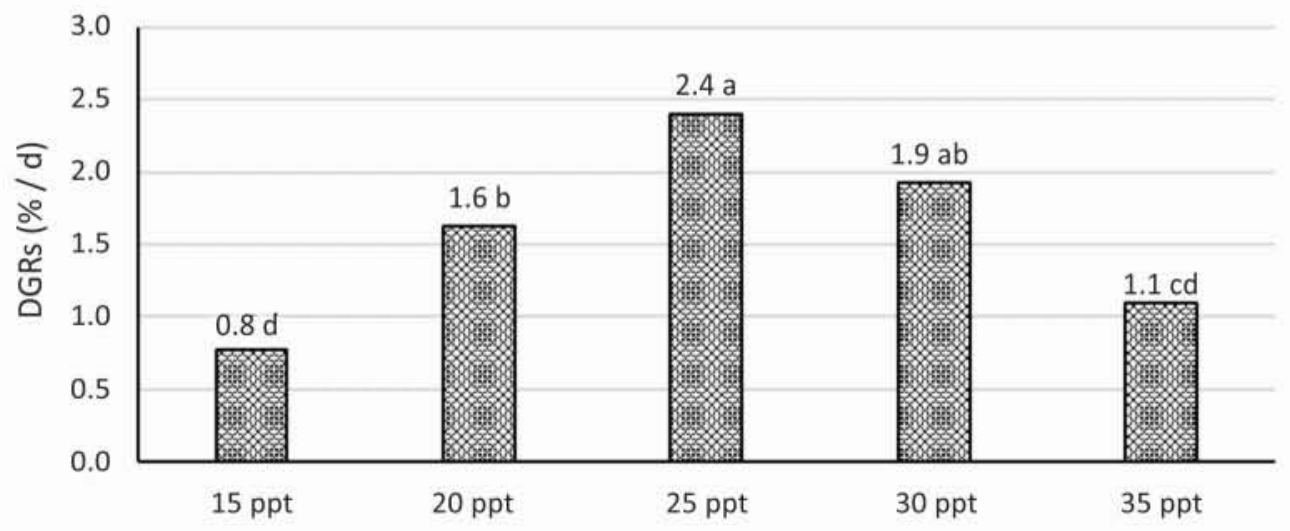

Figure 1 Daily growth rates (DGRs) of Kappaphycus alvarezii non-transgenic plantlets for 12 weeks in PES medium with $15-35$ ppt salinity

Note: Numbers followed by the same letter are not significantly different, based on Duncan's multiple-range test at $\mathrm{P}<0.01, \mathrm{n}=3$. 


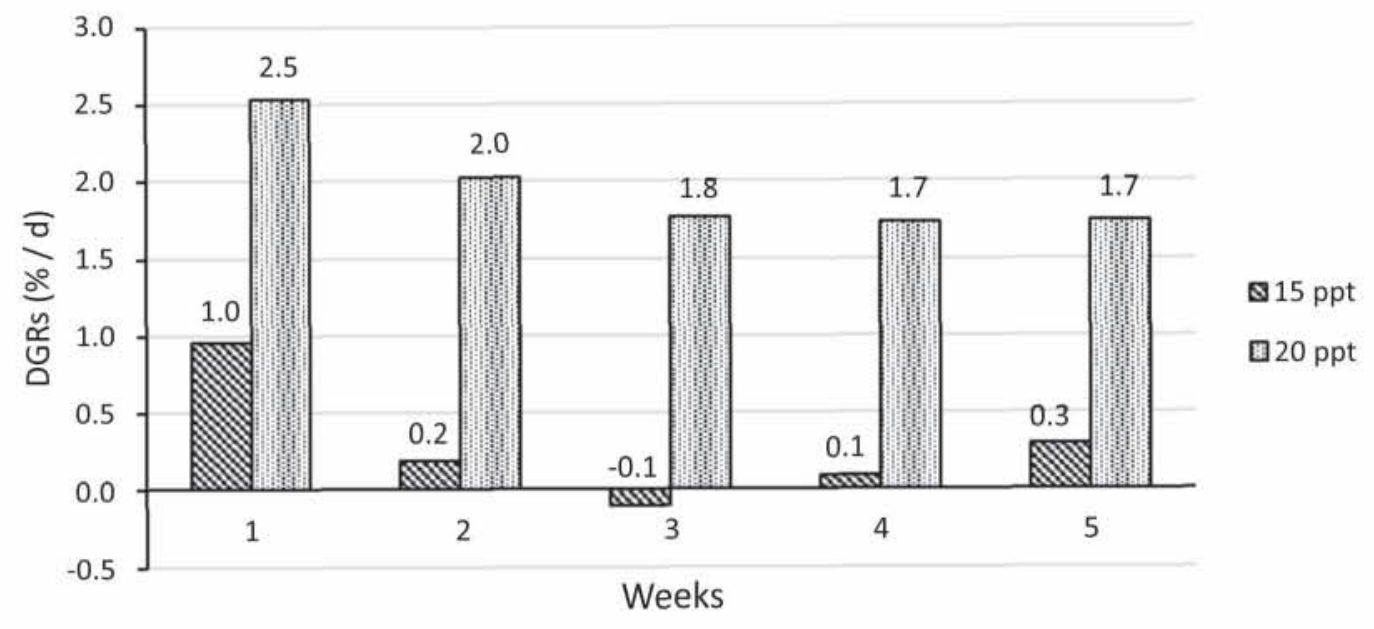

Figure 2 Daily growth rates (DGRs) of non-transgenic plantlets in PES medium with at 15 and 20 ppt salinity levels for $1-5$ weeks of rearing

At $15 \mathrm{ppt}$, a small part of the thalli of nontransgenic plantlets was still brown, especially at its base and tip (Fig. 3A). The brown part of the thallus grew thicker, which caused the DGRs to increase again at the fourth week (Fig. 2). At the $7^{\text {th }}$ week, in the brown part of the thallus, many buds grew, but thallus branches did not grow until the $12^{\text {th }}$ week of maintenance at $15 \mathrm{ppt}$ salinity, with the thallus buds remaining short (Fig. 3B). When the plantlets were subcultured in PES medium with normal salinity (30 ppt), the thallus buds began to form thallus branches, whereas the bleached part of the thallus did not grow (Fig. 3C). After 2 months, the regenerated part of thallus began to separate itself from the bleached thallus and grew normally.
At a salinity of $20-35 \mathrm{ppt}$, all of the plantlet thalli were still reddish brown. Under hyposaline condition (20 ppt) (Fig. 4A), the plantlets formed more thallus branches than those under normal salinity (25 and $30 \mathrm{ppt}$ ) (Figs. 4B and 4C), but the thallus branches were short. In contrast, in hypersaline conditions (35 ppt), plantlets formed fewer thallus branches than those under normal salinity (Fig. 4D), and the thallus plantlets grow elongated. The results of this study indicated that the condition of the thallus branches can be used as an indicator of whether $K$ alvarezii grows in coastal waters with appropriate salinity seawater, hyposalinity or hypersalinity.
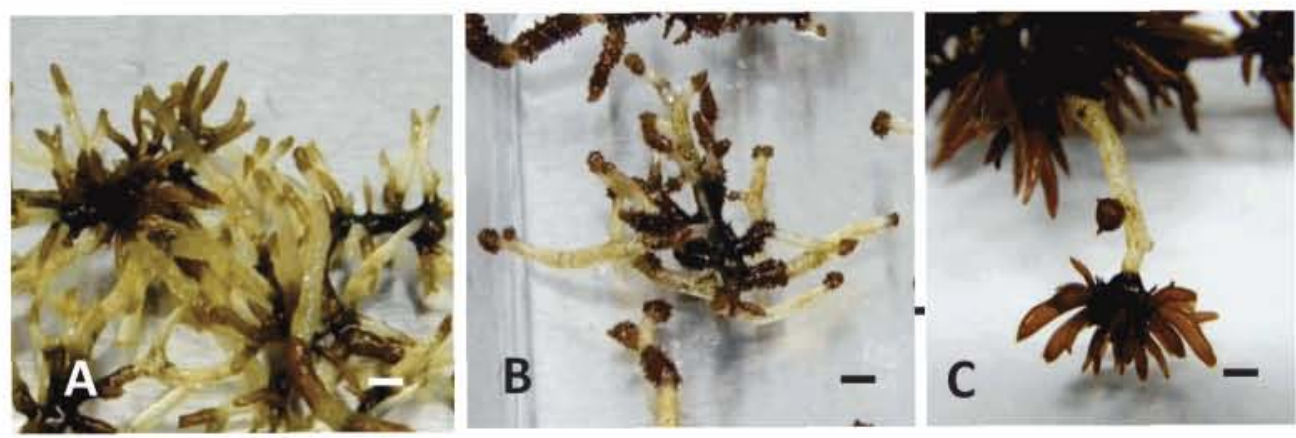

Figure 3 Development of $K$. alvarezii non-transgenic plantlets in PES medium with 15 ppt salinity: (A) most part of the thallus was bleached at the second week; (B) Growth of thallus buds at the brown part of the thallus at the seventh weeks; (C) Growth of thallus branches after plantlets had been subcultured in PES medium with normal salinity $(30 \mathrm{ppt})$

Note: Scale bars $=2 \mathrm{~mm}$. 

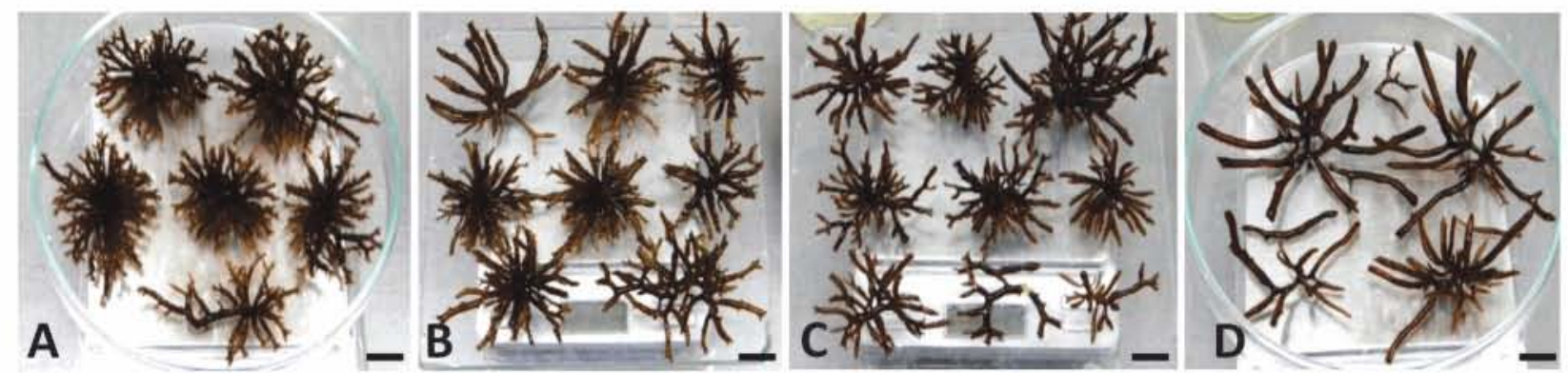

Figure 4 Comparison of thallus branches of non-transgenic plantlets after 12 weeks in PES medium with different salinity: (A) $20 \mathrm{ppt}$; (B) $25 \mathrm{ppt}$; (C) $30 \mathrm{ppt}$; and (D) $35 \mathrm{ppt}$

Note: Scale bars $=10 \mathrm{~mm}$.

Tolerance of Transgenic Plantlets in Hyposaline Conditions

Based on the experimental results obtained in non-transgenic plantlets, six transgenic plantlets of $K$ alvarezii (L7, E2, E3, E5, E6, E7 and E8) and one nontransgenic $(\mathrm{N})$ plantlet were grown on PES medium only with a salinity of 15,20 and 30 ppt for 5 weeks to test its tolerance to hyposaline stress. The result showed that at normal salinity, all of the transgenic plantlets had a significantly higher DGR $(2.1-3.4 \% / \mathrm{d})$ than that of non-transgenic ones $(1.4 \% / \mathrm{d})$ (Fig. 5). At 20 ppt salinity, all transgenic plantlets had higher DGRs $(1.7-2.3 \% / \mathrm{d})$ than that of non-transgenic ones under normal salinity $(1.4 \%$ / d) (Fig. 5), whereas non-transgenic plantlets had lower DGRs $(0.8 \%$ / d) than that of non-transgenic ones in normal salinity. At 20 ppt salinity, non-transgenic and transgenic plantlets still survived, the color of the thalli was still brown (Fig. 6), but in the nontransgenic, most of the thallus brown color has faded (Fig. 6A). This shows that the tolerance of transgenic plantlets to $20 \mathrm{ppt}$ salinity was higher than non-transgenic plantlets, because they can still grow faster than normal in these salinity, whereas the growth of non-transgenic plantlets was stunted or lower than the growth in normal salinity conditions. These results showed that overexpression of the $G a$ gene increased the DGRs of transgenic plantlets under the condition of normal salinity and 20 ppt. This is because the $G \alpha$ protein plays a role in regulating cell proliferation and promoting growth as had been studied in Arabidopsis plants (Ullah 2001; Chen et al. 2006; Colaneri et al. 2014) and rice (Izawa 2010).

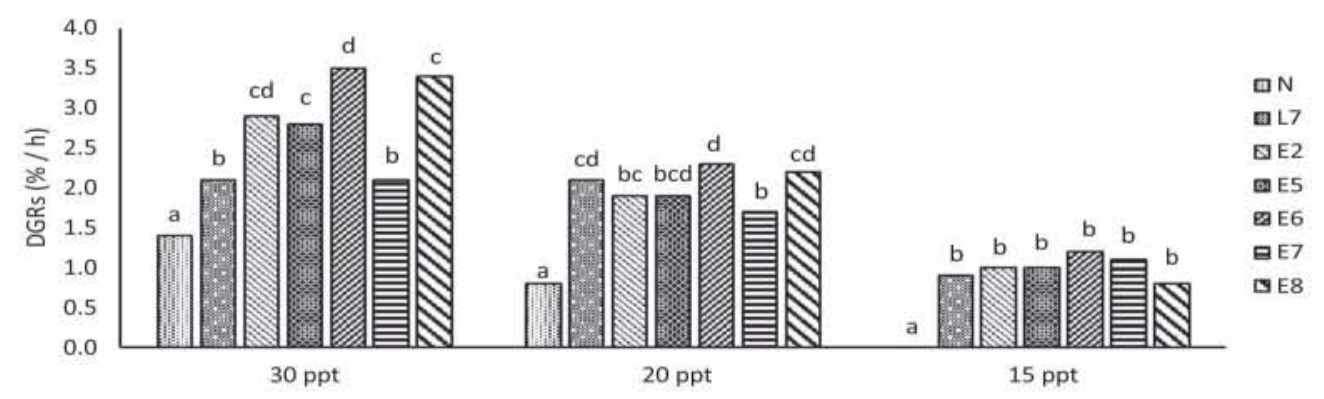

Figure 5 Daily growth rates (DGRs) of non-transgenic $(N)$ and transgenic (L and E) plantlets under normal salinity (30 ppt) and hyposalinity (15 and $20 \mathrm{ppt}$ ) for 5 weeks observation.

Note: Columns followed by the same letter are not significantly different based on Duncan's multiple-range test at $\mathrm{p}<0.01, \mathrm{n}=3$ ). 


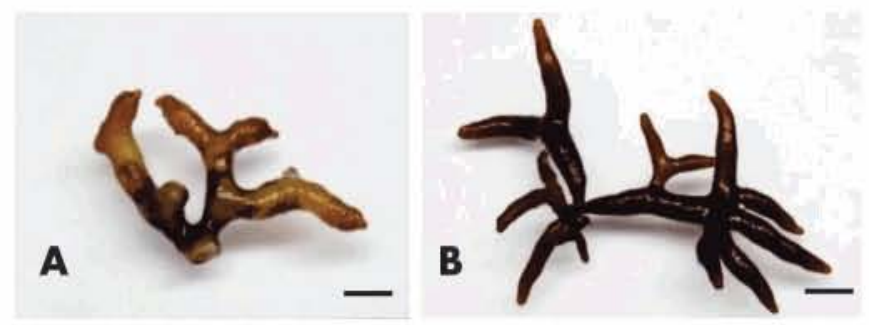

Figure 6 Development of non-transgenic and transgenic thalli after 5 weeks at 20 ppt salinity. (A) non-transgenic; (B) transgenic

Note: Scale bars $=5 \mathrm{~mm}$

At 15 ppt salinity, all transgenic plantlets showed higher DGRs $(0.8-1.2 \% / \mathrm{d})$ than those of non-transgenic plantlets $(0.0 \% / \mathrm{d})$ (Fig. 5). In the first week, DGRs of nontransgenic plantlets decreased into $-0.8 \% / \mathrm{d}$ at 15 ppt salinity (Fig. 7). Most parts of the nontransgenic plantlet thalli $(86 \%$ / d) was bleached after 3 days in PES medium with 15 ppt salinity (Fig. 8A), this caused the DGR of nontransgenic plantlets to fall below $0 \% / \mathrm{d}$ during the first 2 weeks. Whereas, most parts of the transgenic plantlet thalli were still brown, with only $3-7 \%$ of the thalli being bleached, until the $5^{\text {th }}$ week of the experiment at $15 \mathrm{ppt}$ salinity (Fig. 8B). Therefore, all of the transgenic plantlets still grew even with a lower DGRs $(0.8-1.2 \% / \mathrm{d})$ than non-transgenic ones under normal salinity $(1.4 \% /$ d). The effect of hyposaline stress on the growth of transgenic plantlets began to be seen in the second week of the experiment. The DGRs of transgenic plantlets was still high in the first week of the experiment $(1-3.5 \% /$ d) (Fig. 7). Based on these results it is expected that, if high rainfall were to occur and seawater salinity were to drop to $15 \mathrm{ppt}$ in coastal waters for 1 week, $K$. alvarezii transgenic seaweed would grow normally. Moreover, under conditions of heavy rainfall for 2 - 5 weeks, transgenic seaweed would survive even with lower DGR than under normal rainfall conditions.

This study showed that overexpression of the $G a$ gene could increase tolerance to hyposaline stress of up to $15 \mathrm{ppt}$. The mechanism of osmotic adjustment still occurs within the transgenic plantlet cells at $15 \mathrm{ppt}$ salinity. This is because the $G \alpha$ protein plays a role in regulating $\mathrm{Ca}^{2+}$ influx to the cytoplasm through ion channels in the plasma membrane (Gelli et al. 1997; Aharon et al. 1998; Thuleau et al. 1998; Zhang et al. 2011). In tomato plants, a constitutively active form of $\mathrm{T} G a 1$ has been shown to increase the probability of $\mathrm{Ca}^{2+}$ channels being open (Aharon et al. 1998). $\mathrm{Ca}^{2+}$ is a central regulator in plant cell physiology and plays an important role in the response to abiotic stresses including hyposaline stress (Pei \& Gilroy 2008).

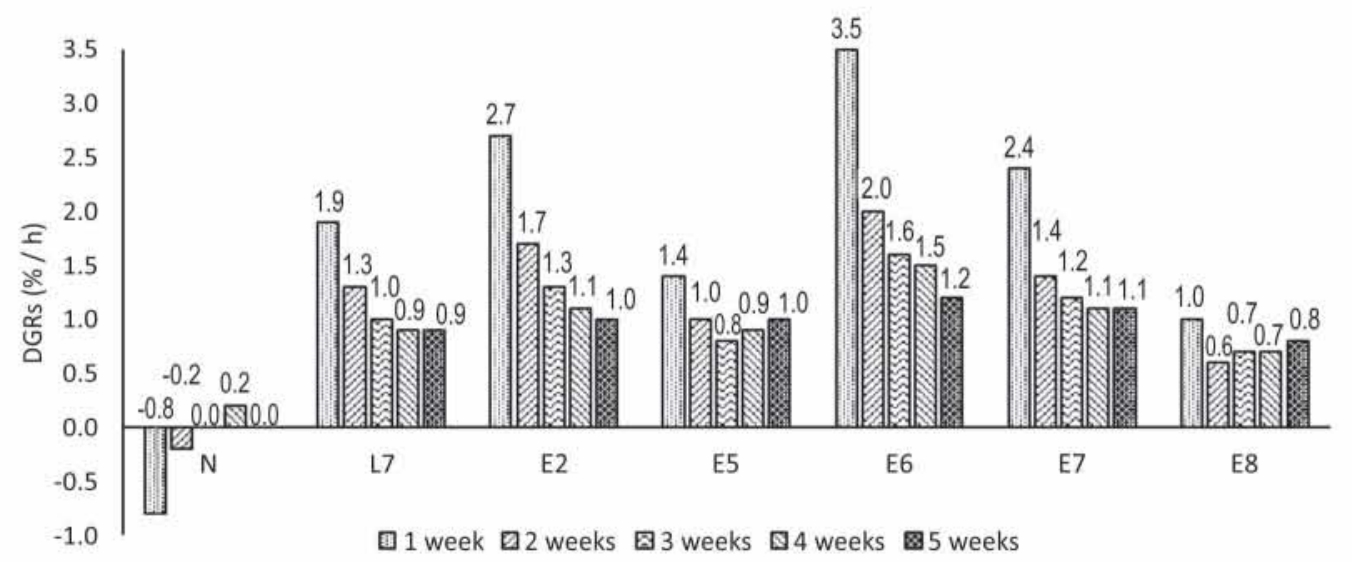

Figure 7 Weekly DGRs of $K$. alvarezii non-transgenic and transgenic plantlets in PES medium with 15 ppt salinity 


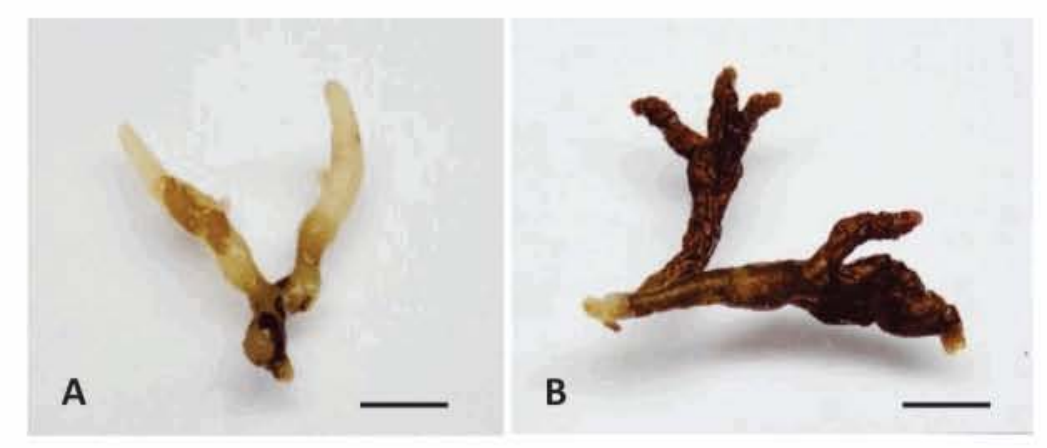

Figure 8 Thalli of $K$. alvarezii non-transgenic (A) and transgenic plantlets (B) in PES medium with 15 ppt salinity Note: Scale bars $=7 \mathrm{~mm}$.

$\mathrm{Ca}^{2+}$ plays a role in activating the SOS1 antiporter and the NHX antiporter. The SOS1 antiporter mediates the movement of $\mathrm{Na}^{+}$in both directions from the apoplast to the cytoplasm through secondary active transport, driven by the $\mathrm{H}^{+}$gradient across the plasma membrane. Meanwhile, the NHX antiporter mediates the movement of $\mathrm{Na}^{+}$in both directions from the vacuole to the cytoplasm (Rodríguez-Rosales et al. 2009). The overexpression of the $G a$ gene increases the $\mathrm{Ca}^{2+}$ influx to the cytoplasm in hyposaline condition, so that activation of SOS1 and NHX antiporter also helps to maintain a balance of $\mathrm{Na}^{+}$concentration between that inside and outside the cells under extreme hyposalinity (15 ppt).

The results of calcium content analysis showed that transgenic plantlets under normal salinity conditions had higher calcium content $(2.49 \%)$ than that in non-transgenic plantlets $(2.06 \%)$ (Fig. 9). This indicated that overexpression of the $G a$ gene increased the $\mathrm{Ca}^{2+}$ concentration in the cytoplasma. The transgenic plantlets in hyposaline conditions had higher calcium content $(5.97 \%$ and $9.27 \%$ ) than that under normal salinity $(2.49 \%)$. Moreover, the calcium content of non-transgenic thalli in hyposaline conditions was lower than that under normal salinity, which was due to most of the non-transgenic thalli experiencing bleaching and being brittle in hyposaline conditions, especially at 15 ppt.

$\mathrm{Ca}^{2+}$ is a structural component of cell walls and membranes in seaweed (Hurd et al 2014). Increased $\mathrm{Ca}^{2+}$ concentrations in the cytoplasm caused the thalli of transgenic plantlets to thicken and become more rigid at salinity level of $15 \mathrm{ppt}$ (Fig. 10B) than at $30 \mathrm{ppt}$ (Fig. 10A). According to Hepler (2005), $\mathrm{Ca}^{2+}$ plays a crucial role in determining the structural rigidity of the cell wall, high content of $\mathrm{Ca}^{2+}$ should increase the rigidity and decrease the plasticity of cell walls. $\mathrm{Ca}^{2+}$ ions also play a role in regulating the flow of water into plant cells, both through apoplast and symplast (Gilliham et al. 2011). Increased rigidity of the $K$. alvarezii transgenic thalli at $15 \mathrm{ppt}$ salinity is an attempt to inhibit excessive influx of water into the cytoplasm under hyposalin conditions. Ion $\mathrm{Ca}^{2+}$ regulates the flow of water into the apolast by affecting the structure of the cell wall. Increased concentration of $\mathrm{Ca}^{2+}$ ions in the cytoplasm stimulates the synthesis of cell wall precursors (cellulose and nonselulose) in the cytoplasm, then these precursors are released into the apolast to form thicker or rigid cell walls (Hawkesford et al. 2012). In the flow of water through the symplast, $\mathrm{Ca}^{2+}$ ions affect the opening of aquaporin which regulates the flow of water entering through the plasma membrane into the cytoplasm. A low concentration of $\mathrm{Ca}^{2+}$ ions in the cytoplasm will open aquaporin, while a high concentration of $\mathrm{Ca}^{2+}$ ions in the cytoplasm will close the aquaporin (Gilliham et al. 2011). Therefore, an increase in tolerance of the transgenic plantlet to hyposalin may be due to an increase in $\mathrm{Ca}^{2+}$ ions in the cytoplasm which has closed aquaporin in the plasma membrane so as to prevent excessive inflow of water into the cytoplasm during hyposalin stress.

All of the transgenic plantlet in $15 \mathrm{ppt}$ were subcultured in PES medium with normal salinity. After 2 months, the entirety of transgenic plantlets thallus grew numerous thallus branches and regenerated normally (Fig. 10C). In contrast, in non-transgenic plantlets, only small part of each thallus regenerated normally, i.e., at its base and tip (Fig. 3C). 


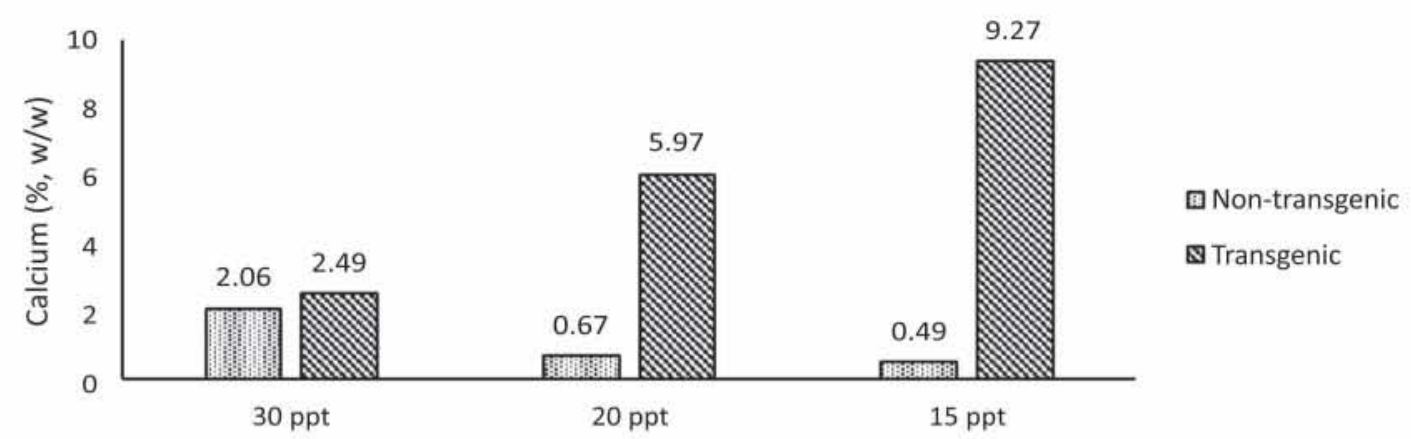

Figure 9 Calcium content of $K$. alvarezii non-transgenic and transgenic plantlets after 5 weeks of culture in PES medium with normal salinity (30 ppt) and hyposalinity (15-20 ppt)
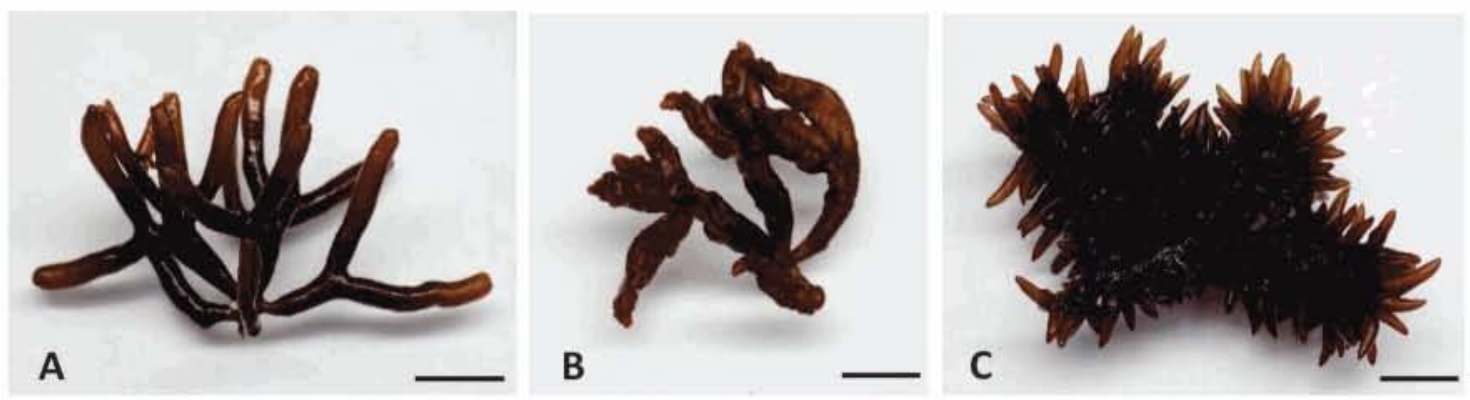

Figure 10 Thallus morphology of $K$ alvarezii transgenic plantlets after 5 weeks of culture at : (A) $30 \mathrm{ppt}$, (B) $15 \mathrm{ppt}$ and (C) $15 \mathrm{ppt}+8$ weeks at $30 \mathrm{ppt}$ Note: Scale bars $=7 \mathrm{~mm}$.

Quantification of $G \alpha$ Gene Expression in Transgenic Plantlets using qPCR.

Two clones of transgenic plantlets (E5 and E6), for which tolerance to hyposalinity had already been proved, and one clone of nontransgenic plantlet $(\mathrm{N})$ were used for expression analysis of the $G a$ gene using qPCR. The expression analysis was performed to determine the change in $G a$ gene expression in transgenic of $K$. alvarezii into which the $G a$ gene with a constitutive CaMV $35 \mathrm{~S}$ promoter had been introduced, compared with that in nontransgenic plantlets. The changes in gene expression were analyzed by $2^{-\Delta \Delta \mathrm{Ct}}$ method. The result showed that the expression of the Ga gene in the E5 transgenic plantlets increased by 6.43 times compared with expression level in nontransgenic plantlets, whereas in E6 transgenic plantlets, it increased by 8.03 times (Fig. 11). The level of transgene expression in transgenic plants is influenced by many factors, especially by the location of the integration of transgene in plant genomes, gene silencing, and promoters that accompany transgene (Page \& Minocha 2004).

The CaMV 35S promoter has been used as a strong and constitutive promoter for expressing transgenes in many different plants, although with different levels of efficiency depending on the species. In dicot plants, the CaMV $35 \mathrm{~S}$ promoter is a very strong constitutive promoter, causing high levels of gene expression. The results of this study showed that CaMV $35 \mathrm{~S}$ promoters could increase expression level of the $\mathrm{Ga}$ gene in transgenic plantlets of $K$. alvarezii (6.43 - 8.03 times) to a level higher than that in transgenic tobacco plantlets (4.96 times) (Fajri 2015). The expression of transgenes using this promoters in transgenic plantlets of $K$. alvarezii has also been reported for the GFP marker gene (Rajamuddin et al. 2014) and the $x$-carrageenase gene (Rajamuddin 2016). The CaMV 35S promoters have also been successfully used to express transgenes in other species of red algae, such as the GUS reporter gene in Porphyra yezoensis (Cheney et al. 2001) and the LacZ reporter gene in Gracilaria gracilis (Huddy et al. 2012). In microalga Chlamydomonas reinhardtii, the CaMV 35S promoter had also successfully expressed the GUS reporter gene ( $\beta$ glucuronidase) (Pratheesh et al. 2012), and in microalga Dunaliella salina, the promoter has successfully expressed the GFP gene reporter (Srinivasan \& Gothandam 2016). 


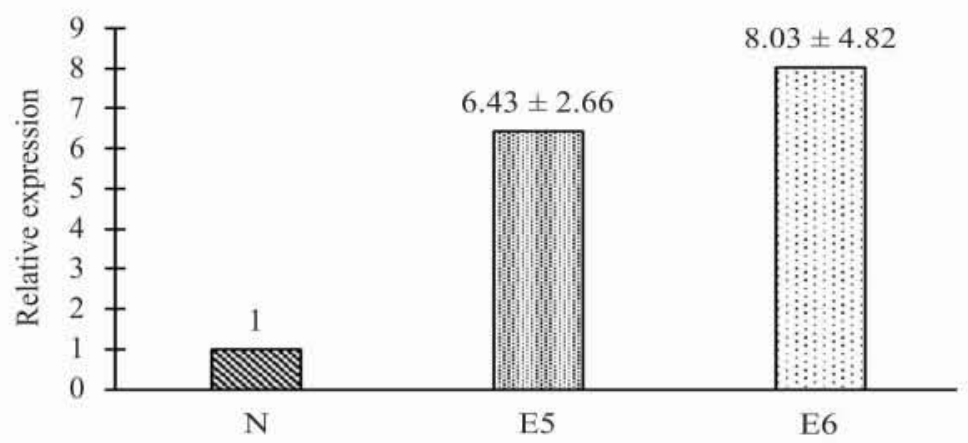

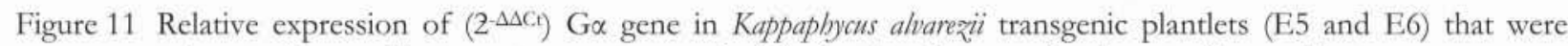
tolerant of hyposalin stress, to non-transgenic $(\mathrm{N})$ plantlets that were intolerant of hyposalin stress

Pearson correlation analysis (Rumsey 2010) was performed on the data of relative $G a$ gene expression (RE) (Fig. 11) and DGRs of nontransgenic and transgenic plantlets in normal salinity $(30 \mathrm{ppt})$ and hyposalinity $(20 \mathrm{ppt}$ and 15 ppt) (Fig. 5). The analysis showed that RE of $G a$ gene had a strong correlation, both with DGRs in normal salinity and hyposalinity because the correlation coefficient was more than 0.7 (Rumsey 2010). The correlation coefficient between RE of $G a$ gene and DGRs at $30 \mathrm{ppt}$ salinity was significant at $1 \%$ test level, whereas with DGRs at 20 and $15 \mathrm{ppt}$ salinity was significant at $5 \%$ test level (Table 1). The correlation between RE of $G a$ gene and DGRs was linearly positive, where increased expression of the $G a$ gene was strongly associated with an increase in DGRs (Fig. 12).

Results of correlation analysis showed that the increase in daily growth rate of transgenic plantlets, both in normal salinity and hyposalinity (Fig. 5) was strongly associated with an increased $G a$ gene expression in transgenic plantlets (Fig. 11). This proved that over-expression of the $G a$ gene had increased the growth of $K$. alvarezii transgenic. As reported in Arabidopsis and rice plants, $\mathrm{G} \alpha$ protein was a positive modulator of cell division processes (Ullah et al. 2001; Chen et al. 2006; Colaneri et al. 2014; Izawa et al. 2010).

Table 1 Results of Pearson correlation analysis between the relative expression of the Ga gene and the daily growth rate (DGRs) in normal salinity (30 ppt) and hyposalinity (20 and $15 \mathrm{ppt})$

\begin{tabular}{ccc}
\hline DGR & Significance value & Correlation coefficient \\
\hline 30 ppt salinity & $0.009^{* *}$ & 0.806 \\
$20 \mathrm{ppt}$ salinity & $0.020^{*}$ & 0.749 \\
$15 \mathrm{ppt}$ salinity & $0.028^{*}$ & 0.724 \\
\hline
\end{tabular}

Notes: $* *=$ Correlation coefficient is significant at $1 \%$ test level.

* = Correlation coefficient is significant at $5 \%$ test level.

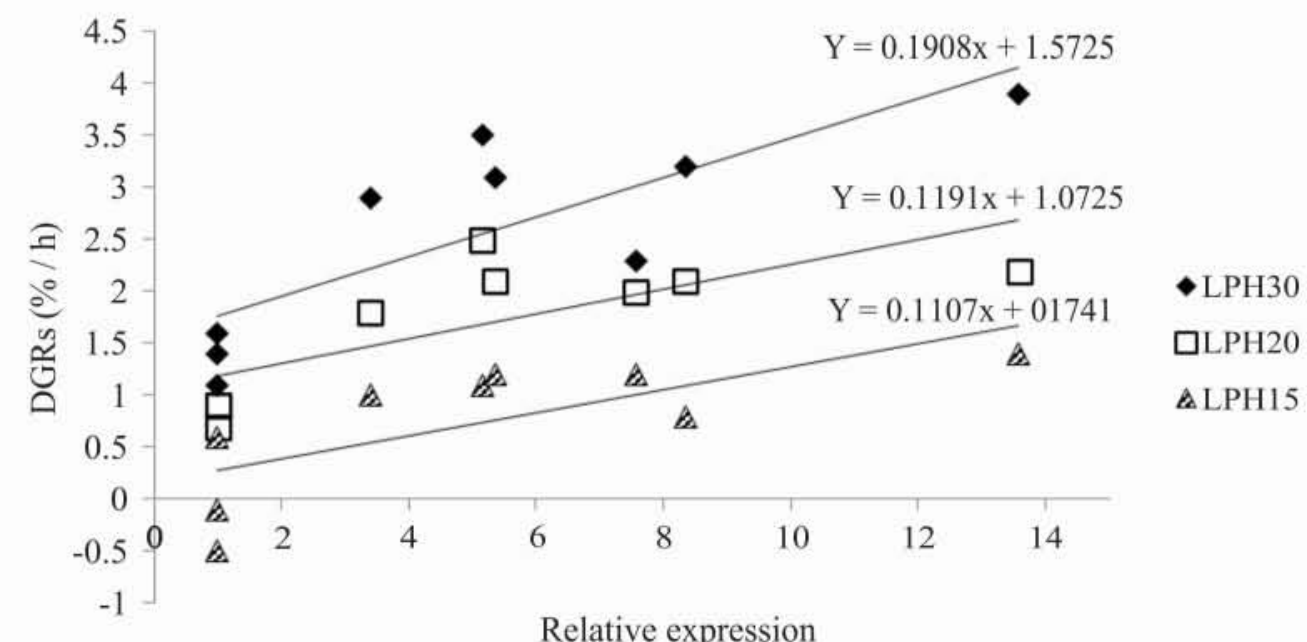

Figure 12 Correlation between the relative expression (RE) of the $G a$ gene with the daily growth rate of non-transgenic and transgenic plantlets on culture media with normal salinity ( $30 \mathrm{ppt})$ and hyposalinity (20 ppt and $15 \mathrm{ppt})$ 


\section{CONCLUSION}

Transgenic plantlets of $K$. alvarezii had a significantly higher daily growth rate than that of non-transgenic plantlets in PES medium with normal salinity ( $30 \mathrm{ppt})$ and hyposalinity (15 and 20 ppt). The transgenic plantlets showed tolerance to hyposalinity at $15 \mathrm{ppt}$. The transgenic plantlets which a high daily growth rate and tolerance to hyposalinity had a higher expression level of the $G a$ gene than that in nontransgenic plantlets.

\section{ACKNOWLEDGEMENTS}

We thank SEAMEO BIOTROP Southeast Asian Regional Center for Tropical Biology for the support of materials and facilities for conducting this research. We also thank the late Dr Utut Widyastuti who provided materials and research direction to the authors.

\section{REFERENCES}

Aharon GS, Gelli A, Snedden WA, Blumwald E. 1998. Activation of a plant plasma membrane $\mathrm{Ca}^{2+}$ channel by TGa1, a heterotrimeric G protein $\alpha$ subunit homologue. FEBS Lett 424:17-21.

Anderberg HI, Danielson J, Johanson U. 2011. Algal MIPs, high diversity and conserved motifs. BMC Evol Biol. 11:110.

Badan Standarisasi Nasional. 2011. Cara Uji Kimia Bagian 5: Penentuan Kadar Logam Berat Timbal (Pb) dan Kadmium (Cd) pada Produk Perikanan. No. SNI 2354.5:2011. Jakarta (ID): BSN.

Chakraborty N, Sharma P, Kanyuka K, Pathak RR, Choudhury D, Hooley R, Raghuram N. 2015. G protein $\alpha$ subunit (GPA1) regulates stress, nitrate and phosphate response, flavonoid biosynthesis, fruit/seed development and substantially shares GCR1 regulation in Arabidopsis thaliana. Plant Mol Biol 89 (6):559-76.

Chen JG, Gao Y, Jones AM. 2006. Differential roles of Arabidopsis heterotrimeric G-protein subunits in modulating cell division in roots. Plant Physiol 141:887-97.

Cheney DP, Metz B, Stiller J. 2001. Agrobacterium-mediated genetic transformation in themacroscopic marine red alga Porphyra yezoensis. J Phycol 7 (Supplement):11-2.

Colaneri AC, Tunc-Ozdemir M, Huang JP, Jones AM. 2014. Growth attenuation under saline stress is mediated by the heterotrimeric $G$ protein complex. BMC Plant Biol 14:129.

Dawes CJ, Lluisma AO, Trono GC. 1994. Laboratory and field growth studies of commercial strains of Eucheuma denticulatum and Kappaphycus alvarezii in the Philippines. J Appl Phycol 6:21-4.

Fajri H. 2015. Genetic engineering of Nicotiana tabacum SR1 with $\mathrm{Ga}$ Gene [thesis]. Bogor (ID): Institut Pertanian Bogor.

Gelli A, Higgins VJ, Blumwald E. 1997. Activation of plant plasma membrane $\mathrm{Ca}^{2+}$-permeable channels by race-specific fungal elicitors. Plant Physiol 113:269-79.

Gilliham M, Dayod M, Hocking BJ, Xu B, Conn SJ, Kaiser BN, ... Tyerman SD. 2011. Calcium delivery and storage in plant leaves: exploring the link with water flow. J Exp Bot 62 (7):2233-50.

Hasegawa PM. 2013. Sodium $\left(\mathrm{Na}^{+}\right)$homeostasis and salt tolerance of plants. Env Exp Bot 92:19-31.

Hawkesford AM, Horst W, Kichey T, Lambers H, Schjoerring J, Moller IS, White P. 2012. Function of macronutrients. In Marschner $\mathrm{P}$, editor. Marschner's Mineral Nutrition of Higher Plants. Third Edition. London (UK): Elsevier.

Hayashi L, Faria GSM, Nunes BG, Zitta CS, Scariot LA, Rover T, Felix MRL, Bouzon ZL. 2010. Effects of salinity on the growth rate, carrageenan yield, and cellular structure of Kappaphycus alvarezii (Rhodophyta, Gigartinales) cultured in vitro. J Appl Phycol 23(3):439-47.

Hepler PK. 2005. Calcium: a central regulator of plant growth and development. Plant Cell 17:2142-55.

Huddy SM, Meyers AE, Coyne VE. 2012. Transformation of lac $\mathrm{Z}$ using different promoters in the commercially important red alga, Gracilaria gracilis. Afr J Biotech 11(8):1879-85.

Hurd CL, Harrison PJ, Bischof K, Lobban CS. 2014. Seaweed Ecology and Physiology. Cambridge (UK): Cambridge University Press.

Izawa Y, Takayanagi Y, Inaba N, Abe Y, Minami M, Fujisawa Y, .... Iwasaki Y. 2010. Function and expression pattern of the $\alpha$ subunit of the heterotrimeric $\mathrm{G}$ protein in rice. Plant Cell Physiol 51(2):271-81.

Karsten U. 2012. Seaweed Acclimation to Salinity and Desiccation Stress. In Wiencke C, Bischof K, editor. Seaweed Biology: Novel Insight into Ecophysiology, Ecology and Utilization. Berlin Heidelberg. Springer-Verlag. p. 87-108.

Liu W, Ming Y, Li P, Huang Z. 2012. Inhibitory effects of hypo-osmotic stress on extracellular carbonic anhydrase and photosynthetic efficiency of green alga Dunaliella salina possibly through reactive oxygen species formation. Plant Physio Biochem 54:43-8. 
Livak KJ, Schmittgen TD. 2001. Analysis of relative gene expression data using real time quantitative PCR and the 2- $\Delta \Delta \mathrm{Ct}$ method. Methods 25:402-08.

Parenrengi A, Rachmansyah, Suryati E. 2011. Budidaya Rumput Laut Penghasil Karaginan (Karaginofit). Jakarta (ID): Badan Penelitian dan Pengembangan Kelautan dan Perikanan. Kementerian Kelautan dan Perikanan.

Page AF, Minocha SC. 2004. Analysis of gene expression in transgenic plants. In Pena L, editor. Transgenic Plants: Methods and Protocols. Series: Methods in Mol Biol 286:291-311.

Pei ZM, Gilroy S. 2008. Calcium signal and their regulation. Ann Plant Rev 33:137-62.

Pratheesh P'T, Shonima GM, Jiji Thomas, Abraham CI, Muraleedhara Kurup G. 2012. Study on efficacy of different Agrobacterium tumefaciens strains in genetic transformation of microalga Chlamydomonas reinhardtii. Adv Appl Sci Res 3(5):2679-86.

Provasoli L. 1968. Media and prospects for the cultivation of marine algae. In Watanabe A, Hattori A, editors. Cultures and Collection of Algae. Proceedings. USJapan Conference. Hakone Japan. Japanese Society of Plant Physiology.

Rajamuddin MAL, Alimuddin, Widyastuti U, Faizal I. 2014. Evaluation of different promoters driving the GFP reporter gene in seaweed Kappapbycus alvarezii. Indonesian J of Biotech 19(2):129-35.

Rajamuddin MAL. 2016. Transformation of Kappa(x)Carrageenase gene in seaweed Kappaphycus alvarezii. [Dissertation]. Bogor (ID): Institut Pertanian Bogor.

Rodríguez-Rosales MP, Gálvez FJ, Huertas R, Aranda MN, Baghour M, Cagnac O, Venema K. 2009.
Plant NHX cation/proton antiporters. Plant Signal Behav 4:265-76.

Rumsey D. 2010. Statistics Essentials for Dummies. Indianapolis (USA): Wiley Publishing, Inc.

Srinivasan R, Gothandam KM. 2016. Synergistic action of D-glucose and acetosyringone on Agrobacterium strains for efficient Dunaliella transformation. PLoS One 11(6): e0158322. DOI:10.1371/journal.pone. 0158322

Sulistiani E, Yani SA. 2014. Kultur Jaringan Rumput Laut Kotoni (Kappapbycus alvarezii). Bogor (ID): SEAMEO BIOTROP.

Sulistiani S, Suharsono, Supena EDJ, Miftahudin. 2019. Agrobacterium-mediated genetic transformation of seaweed Kappaphycus alvarezii using $G a$ gene and callus cultures. BIOTROPIA 26(1):50-60.

Thuleau P, Schroeder JI, Ranjev R. 1998. Recent advances in the regulation of plant calcium channels: evidence for regulation by G-proteins, the cytoskeleton and second messengers. Curr Opin Plant Biol 1:424-7.

Ullah H, Chen JG, Young JC., Im KH, Sussman MR, Jones AM. 2001. Modulation of cell proliferation by heterotrimeric $\mathrm{G}$ protein in Arabidopsis. Science 292:2066-69.

Urano D, Chen JG, Botella JR, Jones AM. 2013. Heterotrimeric $G$ protein signalling in the plant kingdom. Open Biol. 3: 120186.

Zhang W, Jeon BW, Assmann SM. 2011. Heterotrimeric G-protein regulation of ROS signalling and calcium currents in Arabidopsis guard cells. J of Exp Bot 62(7):2371-9. 